\title{
TRADITIONAL HOUSE NAMES AS PART OF CULTURAL HERITAGE
}

Klemen Klinar, Matjaž Geršič

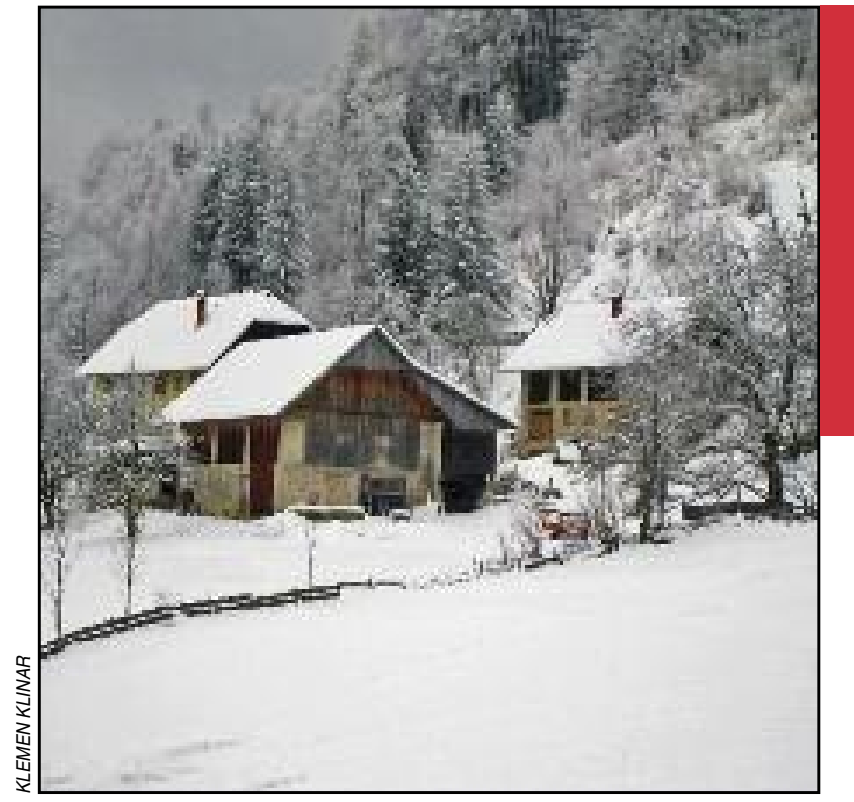

The Pər Smôlijo farm in Srednji Vrh above Gozd Martuljek. 


\section{Traditional house names as part of cultural heritage}

DOI: http://dx.doi.org/10.3986/AGS54409

UDC: 811.163 .6 '373.232.3(497.452)

COBISS: 1.02

ABSTRACT: Traditional house names are a part of intangible cultural heritage. In the past, they were an important factor in identifying houses, people, and other structures, but modern social processes are decreasing their use. House names preserve the local dialect with its special features, and their motivational interpretation reflects the historical, geographical, biological, and social conditions in the countryside. This article comprehensively examines house names and presents the methods and results of collecting house names as part of various projects in Upper Carniola.

KEY WORDS: traditional house names, geographical names, cultural heritage, Upper Carniola, onomastics

The article was submitted for publication on November 15, 2012.

\section{ADDRESSES:}

\section{Klemen Klinar}

Northwest Upper Carniola Development Agency

Spodnji Plavž 24e, SI - 4270 Jesenice, Slovenia

Email:klemen.klinar@ragor.si

\section{Matjaž Geršič}

Anton Melik Geographical Institute

Research Centre of the Slovenian Academy of Sciences and Arts

Gosposka ulica 13, SI - 1000 Ljubljana, Slovenia

Email: matjaz.gersic@zrc-sazu.si 


\section{Introduction}

»Preserved traditional house names help determine historical and family conditions, social stratification and interpersonal contacts, and administrative and political structure. Immigration and emigration are very important aspects of social culture and they have left a strong trace in the house names in the Žiri area " (Zorko, cited in Stanonik 2005, frontispiece). A short and concise outline of house names provided by Terezija "Zinka« Zorko reveals that house names have great informative value, and that it is vital to study them as well as collect and preserve this type of cultural heritage.

In onomastics, traditional house names are classified as epithets (Keber 2002, 61). These are names pertaining to a house, farm, or farmstead, or other property. In the Slovenian countryside, the majority of house names continue to be a living part of cultural heritage (Keber 2002, 61; Kotnik Sipec 2004, 7). A house name is usually created when the property is taken over by an owner whose last name differs from that of the former owner, but the house retains its old name (Zorko 2004; 114-115). It was common practice for a house to be named by the neighbors and not the owners themselves (Kotnik 2011, 13-14). House names were created to fulfill the need to differentiate between people in greater detail because personal names no longer sufficed due to social development and progress. The basis for the development of house names is extremely diverse, often reflecting the age of the property. They were often created from the given names of the owners or other household members, both male and female. Their present form contains traces of the phonetic and accentual development of the name in a specific dialect. An important factor in developing house names is professions (especially crafts) and other human activities. The oldest house names developed from topographic conditions. These include choronyms, toponyms, names of landscapes, and hydronyms; common nouns referring to hills are also common (e.g., hrib 'hill', breg 'slope', planina 'mountain pasture'). Many names reflect specific features of the terrain (desolation, fertility, dryness, moisture, lee sides of hills, hilliness, insolation and windiness) or are derived from other natural processes. Ethnonyms (e.g., Lah 'Italian', Oger 'Hungarian', Čič 'Istro-Romanian') and names referring to residents of various regions (e.g., Korošec 'Carinthian', Kranjec 'Carniolan', Dolenjec 'Lower Carniolan', Ziljan 'Gail Valley resident') are also possible sources of house names. Extremely diverse house names also originate from various nicknames (animal names, nicknames referring to the color of one's skin and hair and other physical or psychological special features, nicknames referring to plants, foods and drinks, clothing and shoes, money, measures, ages, times of birth, family relations, handicrafts, tools, and materials). House names were also derived from the status of a property in the village or the function of the structure from which the property developed. Church and administrative functions (e.g., sextons, mayors, and excise officers) were also important motivations for creating house names. The surnames of the original owners are a frequent motivation for creating more recent house names (Štukl 1997, 4-15; Škofic 2001, 30-34; Kotnik Šipec 2004, 7-8; Zorko 2004, 127-128; Hawlina 2008, 47; Klinar 2011, 3).

The first Slovenian discussions on traditional house names can be found in 1856 in the newspaper Kmetijske in rokodelske novice (Agricultural and Handicraft News), in which Janez Bleiweis describes the different vocabulary used in various Slovenian regions. In this context, he reports that when asked »What do you call your house? « people in Inner Carniola would say $S$ zmerjanjem ... 'We use the name...' The same reply was used in Styria and in some places in Lower Carniola, whereas in Upper Carniola they would say »Our place. «Bleiweis suggested that the expression s zmerjanjem was derived from German Spitzname or Spottname 'nickname'. In addition, the German term Vulgarname 'commonly known as' was used, which Bleiweis Slovenized as prikladek. The fact is that there is no clear semantic boundary between the two expressions. In certain areas, such as around Kamnik, Vulgarname was equated with 'surname', and Spottname with 'nickname' (Sln. percovnik or pricovnik; Stanonik 2005, 18). Keber $(2002,61)$ also lists the following Slovenian synonyms: $z$ devek 'nickname', pritikljej or zdeto/priloženo ime (literally, 'added name'), gerdo ime (literally, 'bad name'), and prišvarek or prišvrk (literally, 'slapped-on name'). It is thus clear that this terminology was used differently in different Slovenian areas, which indicates a strong regional component.

The oldest basic sources for studying traditional house names include terriers (Tajnšek 2007, 356). Later on (in the sixteenth and seventeenth centuries), priests began keeping registers. In the eighteenth century, they also began keeping annual reports in Latin (Libri de statu animarum or simply status animarum) in what is now Slovenia; in the same period, land registers also appeared after the introduction of the cadastre, in which a house name (labeled vulgo) was added to the full name of the property owner (Kotnik Šipec 2004, 19-21; Klinar 2011,3-4). Among secondary sources, one should mention the house-name records compiled by Božo Otorepec and kept by the ZRCSAZU Milko Kos Historical Institute (Keber 2002, 61). 


\subsection{Overview of research to date}

Based on data from the Cooperative Online Bibliographic System (COBISS), the hits returned by the search query hišno ime 'house name' demonstrate that many researchers have studied traditional house names in the Slovenian ethnic territory (over 100 researchers have contributed approximately 190 bibliographic units). It must be emphasized that their collection and research was unsystematic, spatially dispersed, and used varying research methodologies. Regarding the researchers' profiles, these types of issues were at the center of interest of not only professionals from various scholarly disciplines, but also individual amateur researchers.

The youngest collectors of traditional house names include primary-school students, who take part in collecting and studying house names in various ways (research camps and term papers; Gliha Komac 1999; Preserje Primary School 2000; Klinar 2011). House names are an attractive undergraduate thesis topic (16 bibliographic units, among them Grivec 2010 and Gumilar 2012), and they are also studied at the highest academic levels. Basic house-name research has been carried out by Zinka Zorko (Hišna imena na Koroškem [Traditional House Names in Carinthia], 2004), Marija Stanonik (Hišna imena v Žireh [Traditional House Names in Žiri], 2005), the ethnochoreologist Mirko Ramovš (Hišna imena v vaseh Ježica, Savlje, Kleče, Mala vas in Stožice [Traditional House Names in the Villages of Ježica, Savlje, Kleče, Mala Vas, and Stožice], 1999), and more recently, primarily by the dialectologist Jožica Škofič (Hišna imena v Kropi [Traditional House Names in Kropa], 2001; Zasnova slovarja gorenjskih hišnih imen [Draft Dictionary of Upper Carniola Traditional House Names], 2005; Hišna imena kot gradivo za dialektološko raziskovanje [Traditional House Names as a Basis for Dialectology Research], 2011) and the dialectologist and comparative linguist Matej Šekli (Hišna imena v Ovčji vasi [Traditional House Names in Valbruna], 2005). By collecting and analyzing house names, dialectologists can study the linguistic features of individual dialects (Škofic 2005, 104).

The work of geographer Klemen Klinar from the Northwest Upper Carniola Development Agency represents an important methodological contribution to research on traditional house names with a great deal of new information. He has published his research findings in a series of publications (a total of twelve booklets) titled Kako se pri vas reče? (What's Your Traditional House Name? e.g., Klinar 2011).

Many amateur house-name collectors are not included in the COBISS database, and so their number must be significantly larger.

From the geographical viewpoint, individual studies usually extend beyond a certain settlement, local community, parish, proto-parish, municipality, and even a wider geographical unit such as valley or plateau. Research conducted in Slovenian territory at various levels has included fifty-three municipalities in all Slovenian regions; the majority of the municipalities covered were in Upper Carniola and more than 120 settlements from all municipalities were included in the research. In ethnically Slovenian cross-border areas, the greatest attention has been dedicated to traditional house names in the Jaun, Rosen, and Gail valleys in Austrian Carinthia; for example, Bertrand Kotnik made a detailed list of house names in this part of Slovenian ethnic territory in Austria in his fifteen-volume collection titled Zgodovina hiš južne Koroške (The History of Houses in Southern Carinthia; 2011). Various writers have also studied house names in the ethnic Slovenian areas in Italy (the Trieste region, Canale Valley, Venetian Slovenia), as well as in the ethnic Slovenian villages in Hungary (Szlovén háznevek 1999).

\section{Work methods}

\subsection{Collecting house names}

In the studies conducted by the Northwest Upper Carniola Development Agency, traditional house names are defined as geographical names for an occupied or non-occupied house with a house number within a settlement, excluding individual outbuildings. This research also included names of separate and auxiliary outbuildings that are not part of the property where people dwelled (e.g., sawmills and flourmills), and community buildings (e.g., rectories and schools; Klinar et al. 2012, 13).

Due to a more detailed definition of traditional house names, only names are being collected that have been in use since 1940 and are thus at least seventy years old. After the Second World War, abandonment 


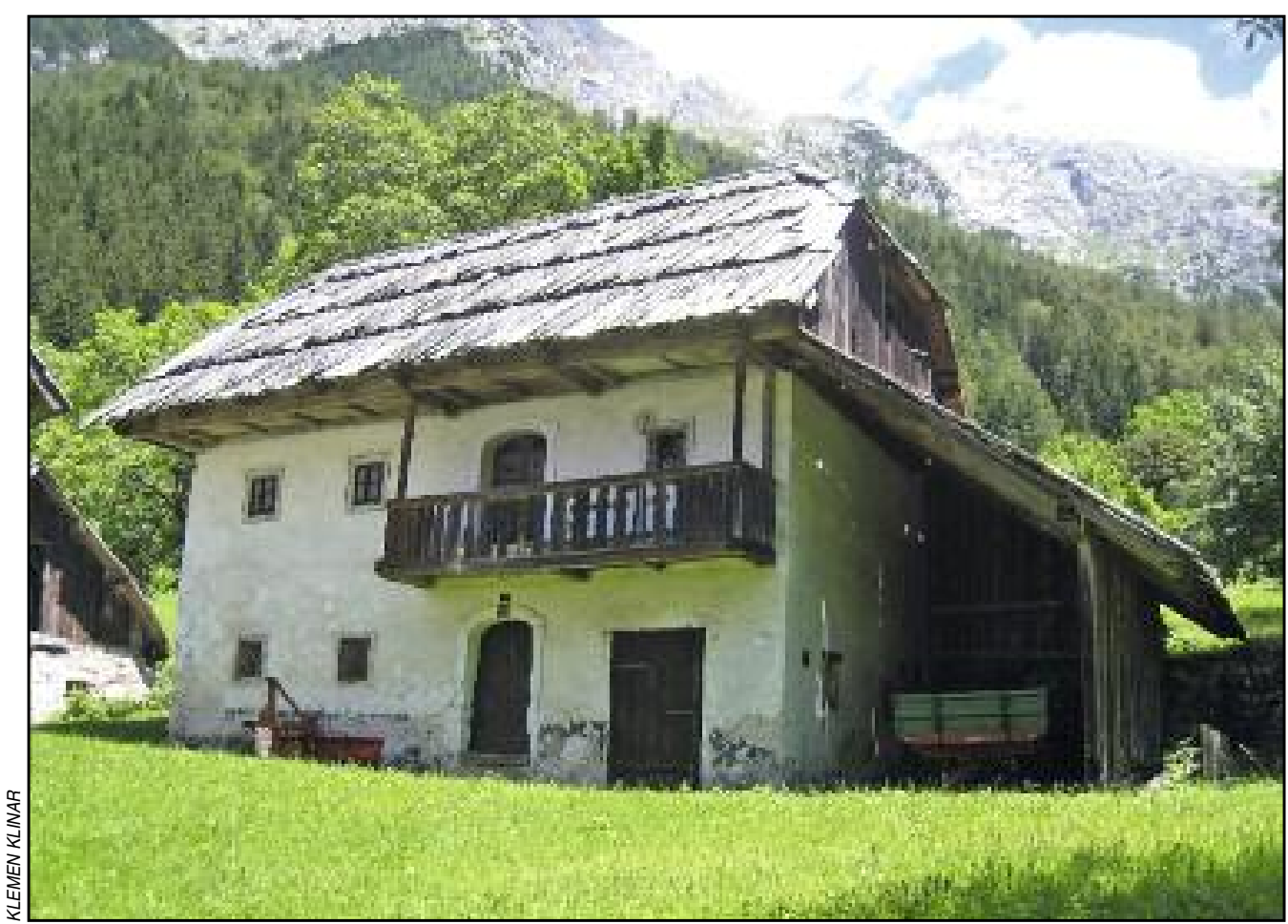

Figure 1: The Par Zdóvankfarm in Kokra.

of farming and urbanization spread widely in the countryside (Klinar et al. 2012, 16); because of this, house names are no longer being created in the former, traditional way.

Historical sources with recorded traditional house names are very useful for identifying the age of house names. Extremely helpful are the protocols of the cadastral survey under Emperor Francis I (1823-1869) and the revised cadastral survey for Carniola (Reambulančni kataster za Kranjsko, 1867-1882), and parish records (the status animarum), in which house names were systematically entered as a separate category. The year of the source is a reliable piece of information, proving that a house name already existed at that time (Klinar et al. 2012, 16).

An overview of written sources is a good basis for fieldwork, in which the selection of good informants is vital. Usually these are locals that have lived in a place their entire lives, speak the authentic local dialect, and know the local home environment and people well (Klinar et al. 2012, 19). Traditional house names are written down and audio recorded during the interviews with the informants. All of the information obtained from them is also presented, verified, and built upon at meetings with the locals, where everyone present is informed about the importance and values of house names and the use of dialect language in general.

\subsection{Transcribing house names}

As part of collecting traditional house names, for best results names are documented in the various forms they appear in:

- Basic form (e.g., Par Tamážovco, Na Pstôt, Fárož);

- Name of the owner derived from the house name (e.g., Tamážovc, Pstôtnek, Ta fárošk);

- Name of the owner's wife derived from the house name (e.g., Tamážovka, Pstôtanca, Ta fároška):

- Possessive adjective derived from the house name (e.g., Tamážovčov, Pstôtnekov, Fárošk). 
As can be seen from the examples listed above, a simplified dialect transcription is used in transcribing traditional house names and related expressions; this dialect transcription can be used to preserve the intangible linguistic cultural heritage in its original dialectal form with great quality, while ensuring that the transcriptions can also be read relatively accurately by locals. In this type of transcription, the stress placement and the vowel length and quality are also marked (e.g., Par Jeglíč and not Par Jéglič); in addition, the vowels reduced to zero are omitted (e.g., Matijovc and not Matijovec), and the reduced vowels and the semivowel a are preserved (e.g., Par Makúč and not Par Mekúć) in addition to other dialect consonant developments (e.g., Par Téfkarjo and not Par Tépkarjo) and other special features, including the substitution of /v/ for /l/ (e.g., Par Gvážarja and not Par Glážarja).

The simplified dialect form has turned out to meet the basic dialectological demands on the one hand and, on the other, it simplifies the scholarly phonetic form to the extent that a specific transcribed name can also be read in its authentic dialect form by locals and visitors. It is also very useful in documenting the dialect differences that appear within the Upper Carniolan dialect group, and the differences with other dialects that are commonly used in Upper Carniola. In the case of uniform standardization, dialect pronunciation as one of the most important heritage components of traditional house names would be lost. This is clearly demonstrated by the examples of identical family names in various dialect forms (Table 1).

Table 1: Examples of identical house names in various dialect forms.

\begin{tabular}{llll}
\hline Standardized form & Dialect form 1 & Dialect form 2 & Dialect form 3 \\
\hline Pri Lizniku & Par Lízneko (Zgoša) & Par Líznek (Bohinjska Bela) & Par Líznjako (Kranjska Gora) \\
Pri Kovaču & Par Kováč (Zabreznica) & Par Kováco (Zgornje Gorje) & Par Kaváć (Rateče) \\
Pri Lazarju & Par Vázarjo (Stara Fužina) & Par Lázarjo (Bohinjska Bistrica) & Par Vázarja (Dobravica pri Podnartu) \\
\hline
\end{tabular}

\section{Results}

\subsection{Scope of research}

Until November 2012, activities for collecting traditional house names in Upper Carniola under the aegis of the Northwest Upper Carniola Development Agency, as the professional project provider, took place as part of three separate projects, of which two have already been finished and one is still ongoing. The first two projects covered sixty-three settlements, and in the current one an additional ninety-three settlements are being processed for house names. The settlements included in individual projects are listed in Table 2.

As part of the two completed projects, 2,131 traditional house names were collected; this number is expected to increase by approximately 1,500 additional names by the time the third project is concluded. Among the names already collected, seventy-four are not connected with any real structure because the property no longer exists.

There is a great diversity of traditional house names because only sixteen appear seven times or more. The names Pri Kovaču 'the blacksmith's place' (27 instances), Pri Mežnarju 'the sexton's place' (18 instances), Pri Žnidarju 'the tailor's place' (14 instances), Pri Španu 'the mayor's place' (12 instances), Pri Mlinarju 'the miller's place' (10 instances), Pri Toncu 'Tony's place' ( 9 instances), and Pri Hribarju 'the hillsman's place' (8 instances) predominated. The following names appeared seven times: Pri Bohincu 'the Bohinj-dweller's place', Pri Grabnarju 'the creek-dweller's place', Pri Kajžarju and Pri Kajžu 'the tenant-farmer's place', Pri Klemencu 'Clement's place', Pri Petru 'Peter's place', Pri Pintarju 'the cooper's place', Pri Ribču 'the fisherman's place', and Pri Šoštarju 'the cobbler's place'. These names confirm that house names were largely derived from the names of occupations or trades (e.g., blacksmith, tailor, and cooper), first names (e.g., Tony, Clement), the location of the property (e.g., on a hill: hillsman, by a creek: creek-dweller), and the status of the property (small farm: tenant-farmer).

\subsection{Marking house names}

So far, collecting traditional house names has yielded twelve publications, with all names provided in dialect and standardized form, and the forms of transcriptions used in historical sources (cf. Klinar 2011). These 
Table 2: Overview of settlements included in individual house-name collection projects in Upper Carniolan municipalities.

\begin{tabular}{|c|c|c|c|}
\hline Municipalities & $\begin{array}{l}\text { What's your house called? } \\
\text { (project concluded in June 2010) }\end{array}$ & $\begin{array}{l}\text { Let's get to know old house names } \\
\text { (project concluded in December 2011) }\end{array}$ & $\begin{array}{l}\text { Nomen vulgare (the project is planned } \\
\text { to conclude by December 2013) }\end{array}$ \\
\hline Bled & $\begin{array}{l}\text { Bodešče, Bohiniska Bela, Koritno, } \\
\text { Kupljenik, Obrne, Ribno, Selo } \\
\text { pri Bledu, Slamniki }\end{array}$ & Rečica pri Bledu, Zasip & Bled \\
\hline Bohinj & - & $\begin{array}{l}\text { Bohinjska Češnjica, Jereka, Podjelje, } \\
\text { Srednja vas, Stara Fužina, Studor }\end{array}$ & $\begin{array}{l}\text { Bohinjska Bistrica, Brod, Kamnje, Laški } \\
\text { Rovt, Polje, Ravne, Ribčev Laz, Savica }\end{array}$ \\
\hline $\begin{array}{l}\text { Cerklje } \\
\text { na Gorenjskem }\end{array}$ & - & - & $\begin{array}{l}\text { Adergas, Ambrož pod Krvavcem, Apno, } \\
\text { Češnjevek, Dvorje, Grad, Praprotna } \\
\text { Polica, Pšata, Ravne, Sidraž, Stiška vas, } \\
\text { Sveti Lenart, Šenturška Gora, Štefanja } \\
\text { Gora, Trata pri Velesovem, Velesovo }\end{array}$ \\
\hline Gorje & $\begin{array}{l}\text { Mevkuž, Podhom, Poljšica } \\
\text { pri Gorjah, Višelnica }\end{array}$ & $\begin{array}{l}\text { Grabče, Krnica, Perniki, Radovna, } \\
\text { Spodnje Laze, Zgornje Laze }\end{array}$ & Spodnje Gorje, Zgornje Gorje \\
\hline Jesenice & - & - & $\begin{array}{l}\text { Blejska Dobrava, Hrušica, Javorniški } \\
\text { Rovt, Koroška Bela, Planina pod Golico, } \\
\text { Plavški Rovt, Potoki, Prihodi, Slovenski } \\
\text { Javornik, }\end{array}$ \\
\hline Jezersko & - & - & Spodnje Jezersko, Zgornje Jezersko \\
\hline Kranj & - & - & $\begin{array}{l}\text { Babni Vrt, Čadovlje, Pangršica, Povlje, } \\
\text { Trstenik, Žablje, Breg ob Savi, Jama, } \\
\text { Mavčiče, Meja, Podreča, Praše }\end{array}$ \\
\hline Kranjska Gora & Gozd - Martuljek, Srednji Vrh & Podkoren, Rateče & Kranjska Gora, Log \\
\hline Naklo & - & - & $\begin{array}{l}\text { Bistrica, Gobovce, Podbrezje, Spodnje } \\
\text { Duplje, Strahinj, Zadraga, Zgornje } \\
\text { Duplje, Žeje }\end{array}$ \\
\hline Preddvor & - & $\begin{array}{l}\text { Bašelj, Breg ob Kokri, Kokra, Mače, } \\
\text { Možjanca, Nova vas, Potoče, Tupaliče }\end{array}$ & $\begin{array}{l}\text { Hraše, Hrib, Preddvor, Spodnja Bela, } \\
\text { Srednja Bela, Zgornja Bela }\end{array}$ \\
\hline Radovljica & $\begin{array}{l}\text { Begunje na Gorenjskem, Brda, } \\
\text { Dvorska vas, Lancovo, Mlaka, } \\
\text { Ravnica, Slatna, Spodnja Lipnica, } \\
\text { Srednja vas, Vošče, Zadnja vas, } \\
\text { Zapuže, Zgornja Lipnica, Zgoša }\end{array}$ & - & $\begin{array}{l}\text { Brezje, Češnjica pri Kropi, Črnivec, } \\
\text { Dobravica, Dobro Polje, Lipnica, } \\
\text { Mišače, Noše, Ovsiše, Peračica, } \\
\text { Podnart, Poljšica pri Podnartu, } \\
\text { Prezrenje, Rovte, Spodnja Dobrava, } \\
\text { Srednja Dobrava, Zaloše, Zgornja } \\
\text { Dobrava }\end{array}$ \\
\hline Šenčur & - & - & $\begin{array}{l}\text { Hotemaže, Luže, Milje, Olševek, } \\
\text { Srednja vas pri Šenčurju, Visoko }\end{array}$ \\
\hline Žirovnica & $\begin{array}{l}\text { Breg, Moste, Selo pri Žirovnici, } \\
\text { Zabreznica, Žirovnica }\end{array}$ & $\begin{array}{l}\text { Breznica, Doslovče, Rodine, Smokuč, } \\
\text { Vrba }\end{array}$ & - \\
\hline
\end{tabular}

small volumes also contain stories connected with house names and old photographs of properties and the villages studied.

What the property owners and other villagers found most interesting were the signs with traditional house names that were put up on all the houses whose owners gave their written consent. In both completed projects, 1,314 properties were recorded in 2010 and 2011, which accounts for $64 \%$ of all the properties identified. This percentage indicates the positive attitude of owners towards cultural heritage. The signs on the properties are ceramic and the house names are written in the simplified dialect form, which was positively accepted by the locals because in this way their house names are presented in authentic dialect form.

After the collection of traditional house names was completed, these names were also included in municipal spatial information systems, such as iObčina (Internet 1) and PISO (Internet 2), and the uniform online geographical information system iSlovenija (Internet 3), where they are displayed as a separate data layer. In addition, all the house names collected are included in the online Encyclopedia of Surnames of the Slovenian 


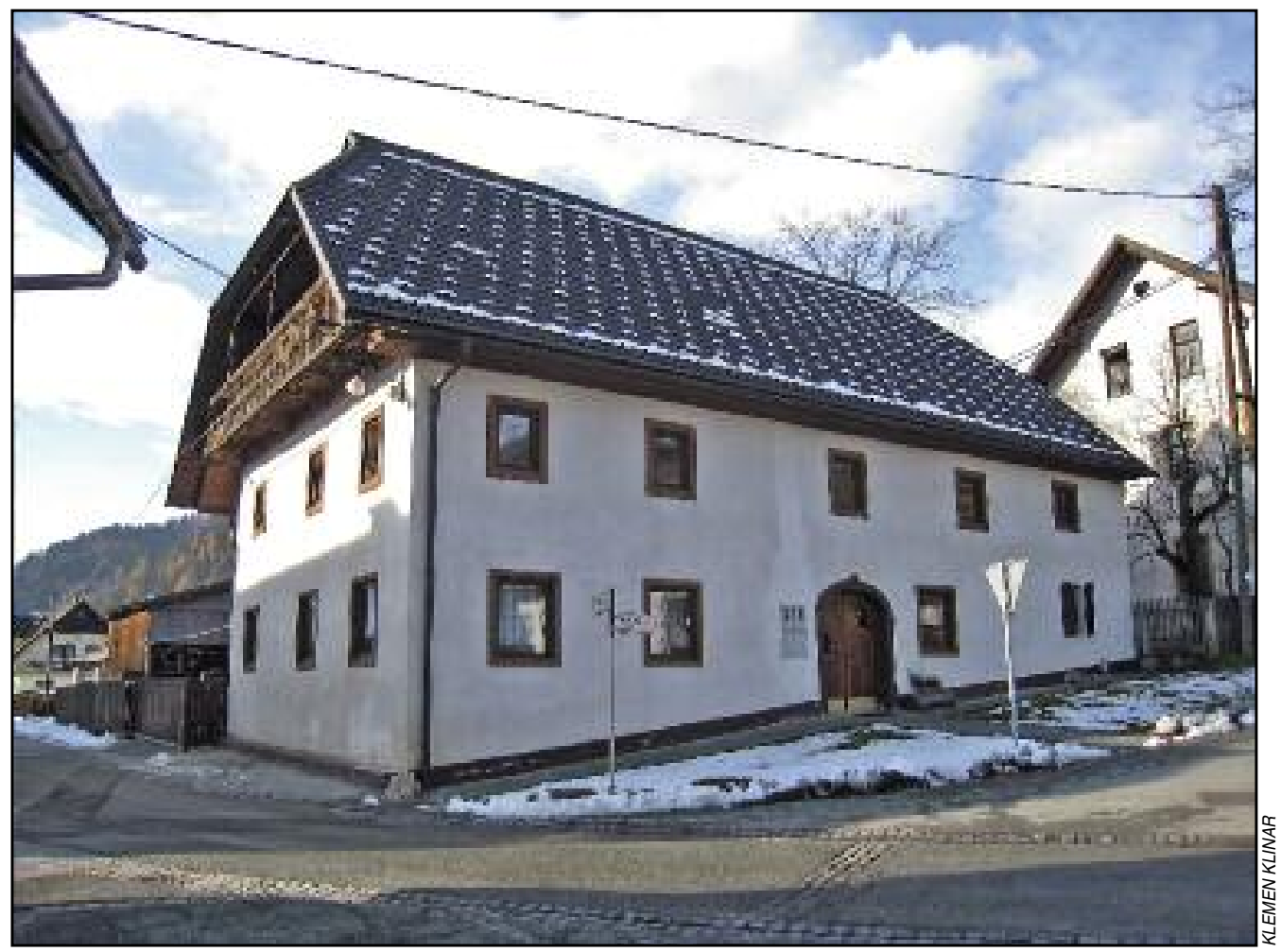

Figure 2: The Pər Mákavčo farm in Podkoren.

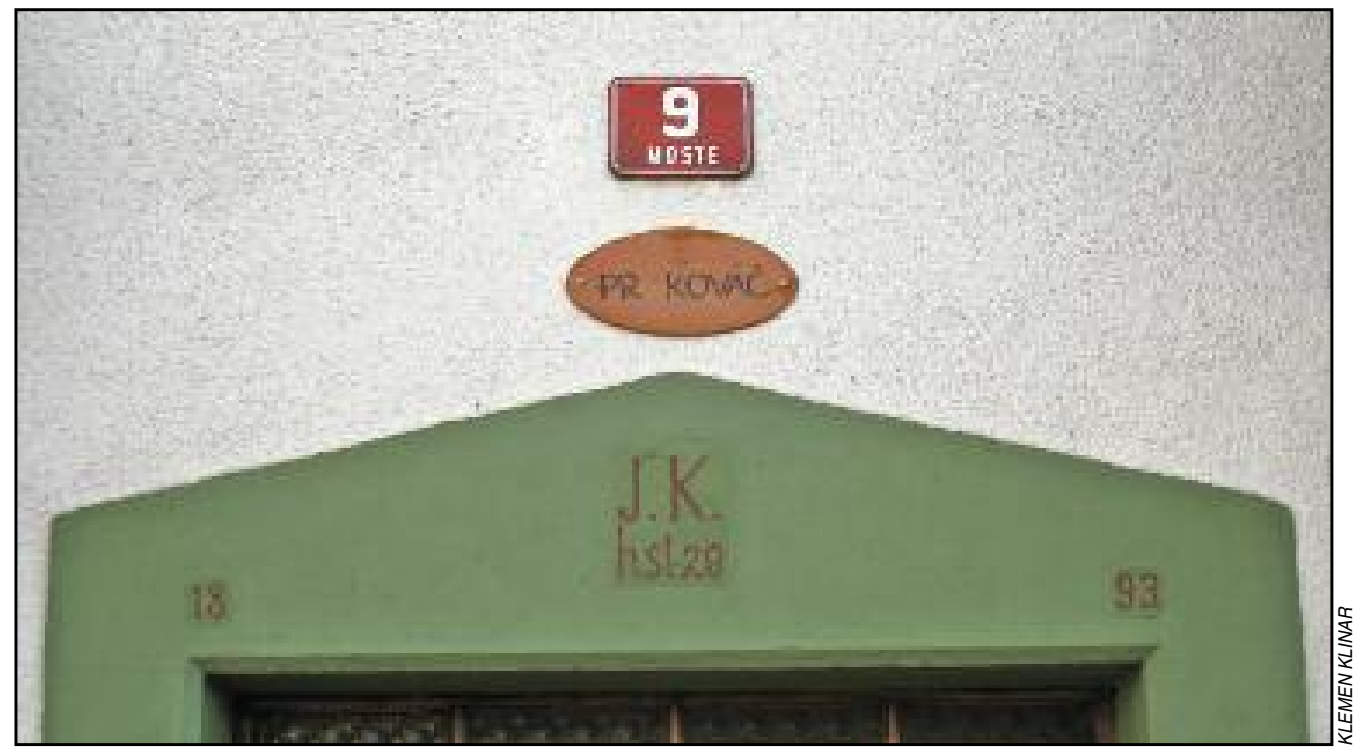

Figure 3: An example of a sign with a house name on it. 
Genealogical Society, where all the surnames and house names from the wider ethnic Slovenian area are gathered in one place (Internet 4).

In addition to the tangible results described above, attention should also be directed to the intangible results of these research projects, which are reflected in local people's increased awareness of the heritage value of traditional house names and thus their everyday usage, and ultimately the need for their transfer to younger generations.

\section{Conclusion}

Traditional house names are an important type of intangible cultural heritage in the Slovenian countryside. »The locals constantly recreate intangible cultural heritage, which is transferred from one generation to the other, as a response to their environment, nature, and history. Intangible cultural heritage provides them with a feeling of identity and continued contact with former generations, which promotes respect for cultural diversity and human creativity « (Internet 5). Modern social processes in the countryside such as suburbanization and abandonment of farming are causing house names to be forgotten and disappear, even though it is these very names that are the elements of the property that do not change and can be preserved for many centuries. Their origins are very diverse and refer to the geographical, social, economic, and other circumstances at the time they were created and, to some extent, they also contain a more direct human aspect.

"Suitably recognized and managed cultural values can significantly influence the sustainable development of rural areas, in which not only economic aspects are important, but also ecological, social, and cultural aspects" (Šmid Hribar, Ledinek Lozej 2013).

Traditional house names are vital for the preservation of dialects and subdialects. Despite the loss of certain dialect features, these are nonetheless preserved in house names, even though younger people no longer use the special features of most dialects in Upper Carniola. House names can also be defined as having cultural heritage value due to their diversity because, with the exception of few rare examples, the great majority of names in the sample areas studied occur less than five times.

Due to the special features of elements of intangible cultural heritage, it is an especially demanding task to identify its worth, values, and threat level (Strategija za varstvo ... 2007, 7-8). All of this points to the necessity of systematic collection and preservation of old house names. The projects by the Northwest Upper Carniola Development Agency have been among the boldest activities in collecting house names to date, supported by uniform methodology and focused on the central and northwestern parts of Upper Carniola.

Collecting traditional house names in Upper Carniola is also supported by other campaigns for collecting choronyms, among which one should highlight the cross-border project FLU-LED Kulturni portal ledinskih in hišnih imen (The Cultural Portal of Choronyms and Traditional House Names), which is being carried out as part of the EU Slovenia-Austria Operational Program, 2007-2013 (Klinar et al. 2012).

In 2010, Slovenian traditional house names and choronyms were accepted onto the UNESCO List of Intangible Cultural Heritage in Austria as the heritage of an officially recognized ethnic minority in Austria (Piko - Rustia 2010,15). This testifies to the great awareness of and respect for this type of Slovenian folk material in Austria, and it encourages us to recognize the importance and place of house names and choronyms in the Register of Intangible Cultural Heritage in Slovenia.

The inclusion of intangible cultural heritage on the UNESCO list opens opportunities for raising the international profile of Slovenian customs, language, traditional trades, and more (Strategija za varstvo 2007,8$)$.

\section{References}

Gliha Komac, N. 1999: Drugi otroški etimološki raziskovalni tabor Stara hišna imena v Kanalski dolini: Žabnice. Hišna imena v Žabnicah - otroški raziskovalni tabor Kanalska dolina 1999. Ukve.

Grivec, B. 2010: Ledinska in hišna imena v izbranih naseljih občine Ormož. Diplomsko delo, Filozofska fakulteta Univerze v Mariboru. Maribor. 
Gumilar, N. 2012: Ledinska in hišna imena v izbranih naseljih občine Grad. Diplomsko delo, Filozofska fakulteta Univerze v Mariboru.

Hawlina, P. 2008: Hišna imena. Drevesa - bilten slovenskih rodoslovcev. Škofja Loka.

Internet 1: http://gis.iobcina.si/gisapp/Default.aspx?a=Gorje (7.11.2012).

Internet 2: http://www.geoprostor.net/piso/ewmap.asp?obcina=ZIROVNICA (7.11.2012).

Internet 3: http://www.islovenija.si (7.11.2012).

Internet 4: http://www.rodoslovje.com (7.11.2012).

Internet 5: http://www.uradni-list.si/1/objava.jsp?urlmpid=20082 (9.11.2012).

Keber, J. 2002: Rojstna imena, hišna imena, vzdevki, psevdonimi v Sloveniji. Jezikoslovni zapiski 8. Ljubljana.

Klinar, K. 2011: Kako se pri vas reče? Hišna imena v naseljih Grabče, Krnica, Perniki, Radovna, Spodnje Laze in Zgornje Laze. Zgornje Gorje.

Klinar, K., Škofic, J., Šekli, M., Piko - Rustia, M. 2012: Metode zbiranja hišnih in ledinskih imen: Projekt FLU-LED v okviru Operativnega programa Slovenija-Avstrija 2007-2013. Jesenice, Celovec.

Kotnik Šipec, M. 2004: Stara hišna imena na Polzeli. Polzela.

Kotnik, B. 2011: Zgodovina hiš južne Koroške. Celovec.

Osnova šola Preserje 2000: Hišna imena v krajevni skupnosti Podpeč-Preserje in krajevni skupnosti Rakitna. Preserje.

Piko - Rustia, M. 2010: Slovenska ledinska in hišna imena »po Unesco«. Novice - tednik za Koroško. Celovec.

Ramovš, M. 1999: Hišna imena v vaseh Ježica, Savlje, Kleče, Mala vas in Stožice. Ljubljana.

Stanonik, M. 2005: Hišna imena v Žireh. Maribor.

Strategija za varstvo kulturne dediščine in naravnih vrednost v Republiki Sloveniji v skladu z mednarodnimi pravnimi instrumenti in aktivnostmi. Gradivo vlade Republike Slovenije. Ljubljana, 2007.

Szlovén háznevek. A Magyarországi szlovének néprajza. Budapest, 1999.

Šekli, M. 2005: Hišna imena v Ovčji vasi. Ovčja vas in njena slovenska govorica: raziskovalni tabor. Ukve.

Škofic, J. 2001: Hišna imena v Kropi. Simpozij Slovenska lastnoimenskost: zbornik s simpozija '99 v Pišecah (ur. J. Toporišič). Novo mesto.

Škofic, J. 2005: Hišna imena kot gradivo za dialektološko raziskovanje. Riječ - časopis za filologiju. Rijeka.

Škofic, J. 2011: Zasnova slovarja gorenjskih hišnih imen. Mednarodni znanstveni sestanek Slovenski dialekti v stiku 5. Koper.

Šmid Hribar, M., Ledinek Lozej, Š. 2013: Vloga prepoznavanja in upravljanja kulturnih vrednot pri razvoju podeželja. Acta geographica Slovenica 53-2. DOI: http://dx.doi.org/10.3968/AGS53402

Štukl, F. 1997: Prispevki k poznavanju domačih imen v zvezi z upravnimi funkcijami. Drevesa - bilten slovenskih rodoslovcev. Škofja Loka.

Tajnšek, R. 2007: Ledinska in hišna imena v okolici Gornjega Grada po urbarju iz leta 1426. Kronika časopis za slovensko krajevno zgodovino. Ljubljana.

Zorko, Z. 2004: Hišna imena na Koroškem (ob Miklošičevem imenoslovju). Zora 31. Ljubljana. 